whether such an ice-cap increased by more than three or four inches yearly, so that from 3000 to 4000 years might easily have elapsed since the incipient birth of the berg in question. Lieut. Greely adrocated future Arctic exploration in the direction of Franz Josef Land.

Mk. Gamel, at whose sole expense the late expedition to the Kara Sea, under Lieut. Hovgaard, was undertaken, intends, provided his enterprise be seconded by the Government, to send his steamer Dijmplina next summer on an expedition, under an officer of the Danish Royal Navy, to the east coast of Greenland, to explore and lay down the coast-line between $66^{\circ} .08$, the farthest northward point attained by Capt. Holms's expedition, and $70^{\circ}$.

AcCording to the Gaztte Géographique, M. Moller, who was recently charged with a mission of botanical investigation to the Island of St. Thomas, has returned to Lisbon. He has brought with him a large number of interesting specimens, not only of the botany, but also of the geology, of the island. These have been placed for investigation in the hands of $M$. Henriques, the Professor of Botany of the Coimbra University. M. Moller has also made some important additions to and corrections in the map of St. Thomas recently published. He has proved that the highest mountain in the island is the Peak of St. Thomas, and that its height is $2 \mathrm{I}_{42}$ metres.

As officer of the French Navy, Commander Réveillère, has succeeded in a daring attempt which he made recently to ascend the rapids of the Meikong, beyond Sambos, in a steamer. Samboc is the chief Cambodian town on the river, and at one time it was thought impossible for a steamer even to reach that point. $\Lambda$ short distance above the town commences a series of rapids, which last for about forty miles, and which in parts appear as formidable obstacles to navigation as the cataracts on the Nile. Commander Réveillère, however, succeeded in overcoming them, but only after such exertion and dan rer as make it clear that in their present state they present an insuperable barrier to navigation for commercial purposes. He proposes a thorough hydrographic study of this section of the river at low water, and he is convinced that the famous barrier will turn out to be merely a mass of trees which has got permanently fixed there and is maintained by annual additions, but which can be removed without difficulty by means of explosives. Beyond the rapids is the town of Stung-Treng, where the greater part of the commerce of the Laos reaches the river, and hence the advantage of a navigable passage. Commander Réveillère concludes his account of his feat by recommending "a serious hydrographic campaign in the rapids of the Meikong, and in the lower Laos." The Meikong is one of the greatest of the great rivers of Asia ; it was first thoroughly explored fifteen years ago by a mission under Lagrée and Garnier, which came to the conclusion that this magnificent water-way was useless for trade purposes on account of its rapids.

LiEUT. Alien has lately returned to San Francisco from a successful exploration of Alaska, undertaken by direction of the United States Government. He left Sitka in February, going to the mouth of the Copper River, which he ascended as far as the great mountain range of Alaska. He crossed the mountains with snow-shoes, coming to the sources of the Tennah, which river he followed for 800 miles to its junction with the Takon, and he descended this latter river to its mouth, a journey of between 400 and 500 miles. From the mouth of the Takon he went to Fort Michael, on Behring's Straits, whence he came home.

Tire proposal that the Netherlands Government should make a grant to the I) utch Geographical Society towards the expenses of the projected scientific expedition for the exploration of the half of New Guinea belonging to Holland has been rejected by the Second Chamber by a large majority, there being forty-nine votes against the motion to twenty-one in favour of it. In the debate most of the speakers expressed their conviction of the desirability of the expedition maintaining the character of a purely private enterprise.

A NEIV edition of Dr. Hunter's "Indian Gazetteer of India " in twelve volumes is in the press. Several of the volumes will be published in the course of the next few weeks.

THE November number of the Austrian Monatsschrift fïr den Orient contains a long communication from Dr. Lenz, from Ango-Ango, with reference to his expedition to the Congo. It deals nainly with the superficial aspects of the various settle- ments on the West Coast of Africa, of the trade there and its future prospects, and especially with the prospects of Austrian trade.

UNDER the title, "La Corée avant les Traités," M. Jametel, a French writer on the Far East, has published, in a brochure of about eighty pages, four articles which he contributed to recent numbers of La Revue de Géographie. He describes the voyage from Nagasaki to Fusan, a Corean port then only opened to Japanese trade, and gives a sketch of the history of the peninsula from early times ; finally he describes the Japanese settlement at Fusan and the neighbouring Corean town of Toraifu, and adds a few words about the Island of Quelpaest. The account is very lively and amusing, but it can hardly be said to add much to our geographical knowledge of Corea, small as that was before the treaties.

\section{CHLOROPHYLL ${ }^{1}$}

$A L L$ who are accustomed to observe vegetation must have been struck with the great variety of shades of green which the foliage of different plants presents. Without pretending to generalise further, it may be stated that, at any rate so far as our common agricultural plants are concerned, they show somewhat characteristic shades of colour, according to the Natural Order to which they belong-the Leguminosæ differing from the Graminex, the Cruciferæ, the Chenopodiaceæ, and so on. But the same description of plant will exhibit very characteristic differences, not only at different stages of growth, but at the same stage in different conditions of luxuriance, as affected by the external conditions of soil, season, manuring, \&c., but especially under the influence of different conditions as to manuring.

The Rothamsted field experiments have afforded ample opportunity for observations of this kind; and it bas been quite evident that, in a series of comparable experiments with the same crop, depth of green colour by no means necessarily implied a finally greater amount of carbon assimilation; whilst we have long ago experimentally proved that the deeper colour was associated with relatively high percentage of nitrogen in the dry or solid substance of the herbage; and this obviously means a lower relation of carbon to nitrogen.

Mentioning these facts to Dr. W. J. Russell, who has devoted so much attention to the subject of chlorophyll, he kindly undertook to make comparative determinations of the amounts of chlorophyll in parallel specimens, in which we were to determine the percentages of dry matter and of nitrogen. Accordingly in June, 1882 , during the period of active vegation, Dr. Russell spent a day at Rothamsted for the purpose of collecting appropriate samples, which were taken from several differentlymanured plots of meadow-grass, wheat, barley, and potatoes, respectively.

The following table gives the results of some of these experiments; namely, the percentages of nitrogen, and the relative amounts of chlorophyll, in the separated gramineous and the separated leguminous plants in the mixed herbage of grass-land; in specimens of wheat grown by a purely nitrogenous manure, and by the same nitrogenous manure with a full mineral manure in addition; and in specimens of barley grown by a purely nitrogenous manure, and by a mixture of the same nitrogenous manure and mineral manure in addition. It is to be borne in mind that the specimens were collected while the plants were still quite green and actively growing. It should be further explained that the amounts of chlorophyll recorded are, as stated in the table, relative and not actual; that is to say, the figures show the relative amounts for the individual members of each pair of experiments, and not the comparative amounts as between one set of experiments and another.

It will be seen in the first place that the separated leguminous herbage of hay contained a much higher percentage of nitrogen in its dry substance than the separated gramineous herbage; and that, with the much higher percentage of nitrogen in the leguminous herbage, there was also a much higher proportion of chlorophyll. Under comparable conditions, however, the Leguminosæ eventually maintain a much higher relation of nitrogen to carbon than the Gramineæ; in other words, in their

I " Note on some Conditions of the Development, and of the Activity, of Chlorophyll." By Prof. J. H. Gilbert, LL.D., F.R.S. Read in Section B at the meeting of the British Association at Aberdeen, September, r 885 (Abstract.) 
case carbon is not assimilated in so large a proportion to the nitrogen taken up.

Next, it is to be observed that the wheat-plants manured with ammonium-salts alone show a much higher percentage of nitrogen than those manured with the same amount of ammonium-salts but with mineral manure in addition. The high proportion of chlorophyll again goes with the high nitrogen percentage; but the last column of the table shows that, with the ammonium-salts without mineral manure, with the high percentage of nitrogen, and the high proportion of chlorophyll, in the dry substance of the green produce, there is eventually a very much less assimilation of carbon. The result is exactly similar in the case of barley; the plants manured with ammonium-salts alone showing the higher percentage of nitrogen, and the higher proportion of chlorophyll, but eventually a much lower assimilation of carbon.

It is evident that the chlorophyll formation has a close connection with the amount of nitrogen assimilated, but that the carbon assimilation is not in proportion to the chlorophyll formed, if there be a relative deficiency of the necessary mineral constituents available. No doubt there has been as much, or more, of both nitrogen assimilated and chlorophyll formed, over a given area, where the mineral as well as the nitrogenous manure had been applied, the lower proportion of both in the dry matter being due to the greater assimilation of carbon, and consequently greater formation of non-nitrogenous substances.

It is of interest to observe that these results of experiments in the field are perfectly consistent with those obtained by vegetable physiologists in the laboratory; they having found that the presence of certain mineral or ash constituents, and especially that of potassium, is essential for the assimilation of carbon, no starch being formed in the grains of chlorophyll without the aid of that substance. Sachs says :- "Potassium is as essential for the assimilating activity of chlorophyll as iron for its production."

\section{Relation between Nitrogen Accumulation, Chlorophyll Formation, and Carbon Assimilation.}

The figures in parentheses represent determinations in the not fully dried substance.

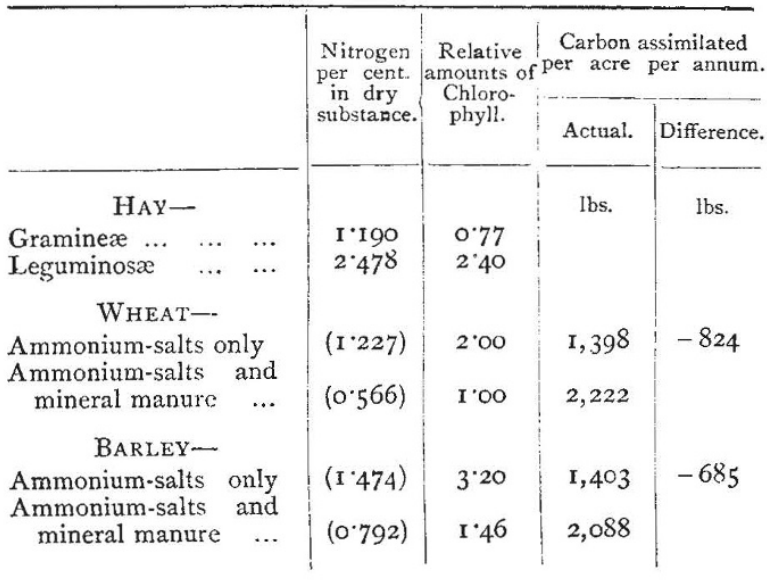

\section{CARTOGRAPHICAL WORK IN RUSSIA IN} $1884^{1}$

THE chief surveys in European Russia are directed towards mapping South Finland, the western frontier on the Dun and Dnieper, and the Government of Taurida. The surveys are made on a scale of 1750 feet to the inch, and the inequalities of soil are represented by horizontal lines received from accurate levellings. Since 1870 about 44,000 square miles have been thus mapped, and, in 1884,6850 square miles were added to the above, the newly-annexed part of Bessarabia included. The geodetical triangulation for this survey was continued in Poland and Grodno. The work for an orographical map of Russia, which must be based on accurate levellings, has been busily continued since $\mathrm{r} 88 \mathrm{r}$, as also telegraphic determinations of longitudes in Poland.

I Izvestia of the Russian Geographical Society, September, 1885 .
Instead of the former map of West and Middle Russia, on r 50 sheets, on the scale of 3 versts $(2$ miles) to an inch, the Topographical Department is now preparing a new map on a larger scale ( 2 versts to an inch), which will be printed on a new method, by helio-engraving, with level-lines in a separate colour. Many preliminary essays having been made, this method has been definitively adopted. The map of Russia (ro versts to an inch) has been completely revised by General Strelbitzky; and the map of the Caucasus, on the same scale, was completed in 1884 . The northern and north.eastern sheets of the map of European Russia will be completely revised in accordance with new surveys.

The map of the Asiatic dominions of the Empire, with the neighbouring regions (I00 versts to an inch), is completed, and is printed in colours. That of the eastern part of the Balkan peninsula is prepared on two different scales 15 and 3 versts to the inch), and on both maps the inequalities of the soil are represented by horizontal lines. The middle parts, including the Balkan ridge, were ready to print. Helio-engraving had also been resorted to, but it required considerable retouching by the engraver.

Leaving aside the purely military maps of Middle Europe and the statistical maps of the St. Petersburg military district, the following maps, published in 1884 , are especially worthy of notice :-The region of the Cossacks of the Ural (Io versts to an inch); the Island of Sakhalin (40 versts); North-Western Mongolia (50 versts), including all the rich materials collected by the expeditions of MM. Potanin, Rafailoff, Orloff, Prjevalsky, Pevtsoff, and several others; Afghanistan (50 versts), according to the surveys and information of M. Lessar; the southwestern Turkoman region, by the same (20 versts); the surveys of M. Kosyakoff in Karategin and Darvaz (15 versts); the survey from Staro-Tsurukhaitu to Aigun, on the Amur (25 versts); a map of China proper, by M. Matusovsky (IOO versts); the plans of Odessa, Nikolaieff, Ekaterinoslav, Bendery, and Elizabethgrad, as also of Plevna and Lovtcha; the neighbourhoods of Kazan and of Novogeorgievsk, and many others.

On the Caucasus, as soon as the triangulation of the region was terminated some fifteen years since, a series of surveys, on scales of 1400,1750 , and 3500 feet to an inch, were undertaken. Large parts of Transcaucasia were thus mapped. Since $188 \mathrm{I}$ the work has been prosecuted in the central parts of the great Caucasus ridge, in Daghestan, and in the Transcaspian region; about 30,000 square miles were thus surveyed. In I 884 the chief surveys were made in the teritory of Merv, along the Murghab ; and on the routes between Kizil-arvat, Petro-alexandrovsk, Khiva, and Merv. The drawing and engraving of the great map of the Caucasus with the neighbouring parts of Persia and Turkey, as also of that of the Transcaspian region, both on a scale of 5 versts to the inch, have been prosecuted.

In Turkestan the chief attention has been directed towards the survey of the former khanate of Kokan, now the province of Ferghana, the work meeting with great difficulties owing to the hilly character of the region and its unhealthy climate. Reconnoitring has been prosecuted in the vassal khanates of Bokhara, west of the Pamir, by a topographer who accompanied Dr. Regel

The mapping of the town of Tashkend, which covers as much as thirty-five square miles, and where trigonometrical measurements meet with great difficulties on account of refraction and the want of wood for the triangulation-pyramids, a system known under the name of Polyoonale Zïge, and which has been greatly extended of late in Germany, has been resorted to. The horizontal angles were measured by a little universal instrument, and the distances by a ribbon, with the help of the eclimetre. The results obtained were very satisfactory. Several new sheets of the ro versts map were printed, as also a map of the neighbourhood of Tashkend.

In the Omsk military district, detailed surveys, based on a geodetical net, have been prosecuted since 1870 to the southwest of the Irtish River, between its sources and Pavlodar. In I 883 and 1884 large spaces in the region between Omsk, Pavlodar, Petropaulovsk, and Kokchetav were mapped, and a series of latitudes and longitudes were determined.

In Eastern Siberia the Government of Irkutsk is now surveyed on a scale of one verst to the inch, the trigonometrical net having been completed in I882. The upper parts of the Vition and Barguzin were reconnoitred, and the trigonometrical net extended in Southern Transbaikalia. On the Pacific coast, the region east of the Suifun River, and on the Chinese frontier, has been surveyed. 